ISA

Arboriculture \& Urban Forestry 2016. 42(2): 102-110

\title{
The Influence of Biochar, Slow-Release Molasses, and an Organic N:P:K Fertilizer on Transplant Survival of Pyrus communis 'Williams' Bon Chrétien'
}

\author{
Emma Schaffert and Glynn Percival
}

\begin{abstract}
High mortality rates result from transplanting bare-rooted plants into urban landscapes where unsuitable soil conditions, such as low fertility and poor structure, often exist. Coupled with little aftercare, these losses can cause high economic losses to the industry. Previous studies have shown lowered transplant stress and higher survival rates through the addition of soil amendments at the time of planting to improve soil conditions. The efficacy of three soil amendments applied singly and in combination-biochar, slow-release molasses, and an organic N:P:K fertilizer-were investigated for their potential to reduce transplant losses of Pyrus communis 'Williams' Bon Chrétien. Results of this investigation showed that use of these soil amendments in virtually all cases had significant positive effects on tree growth and vitality across two growing seasons. For example, all amendments reduced mortality of Pyrus communis 'Williams' Bon Chrétien' by $20 \%$ compared to none in treated controls, while increases in fruit yield and crown canopy coverage per tree ranged from $19.3 \%$ to $46.7 \%$ and $14.4 \%$ to $31.1 \%$ over non-amended soils when averaged over two growing seasons. Amendments of biochar with an organic N:P:K fertilizer and an organic N:P:K fertilizer alone showed, on average, the highest improvements in vitality and growth. Results indicate use of biochar, slow-release molasses, and organic N:P:K fertilizer amendments offer potential for increasing bare-root transplant survival and establishment of Pyrus communis 'Williams' Bon Chrétien.

Key Words. Biochar; Fertilizer; Pyrus communis; Soil Amendments; Transplant Stress; Tree Mortality; Tree Planting; Urban Trees.
\end{abstract}

Benefits of urban greening and urban forestry are increasingly recognized due to the wealth of scientific evidence showing how urban greenspace improves human physical and psychological wellbeing, as well as absorbing atmospheric pollutants and particulates, and reduces the urban heat island effect (Smardon 1988; Nowak et al. 2006; Susca et al. 2011). Research is now focusing on how to better plan, implement, and manage greenscape in urban environments, such as in towns and cities. For economic reasons, bare-rooted ornamental trees and shrubs are predominantly used in greenscape plantings. However, many of these plants are often unsuccessful in establishing after planting with mortality rates frequently ranging from $30 \%$ to $50 \%$ over the first growing season (Hirons and Percival 2012). Lifted bare-rooted tree stock are frequently subjected to large root losses (e.g., up to 98\%) (Wat- son and Himelick 1982) after becoming damaged or detached, resulting in a distorted root:shoot ratio and subsequent development of root defects, such as circling and promotion of irregular lateral root elongation (Hirons and Percival 2012). Additional stressors post-lifting, including desiccation and rough handling, are viewed as the most common cause of transplant mortality, although severity can be species specific, depending on their ability to regenerate roots (McKay et al. 1999). These result in poor root to soil contact, poor root system permeability, and insufficient water uptake to meet the demands of canopy transpirational water losses, which causes internal water deficits (Kozlowski and Davies 1975; Grossnickle 2005).

Stimulation of root growth following transplanting is advocated as a means of reducing transplant losses (Koch 1996; Rolland et al. 2002; Percival and 
Barnes 2007). Consequently, research has evaluated the potential of numerous soil amendments at the time of planting to include mycorrhizae, biostimulants, sugars, and fertilizers. Results have been mixed with some studies demonstrating positive benefits on root vigor following addition of these amendments, while others little, if any positive effects (Hensley et al. 1988; Edmeades 2003; Percival et al. 2004; Percival and Barnes 2007).

Biochar is the solid co-product of biomass pyrolysis, a technique used for carbon-negative production of second-generation biofuels. Biochar can be applied as a soil amendment, where it permanently sequesters carbon from the atmosphere as well as improves soil structure, nutrient retention, and crop productivity (Elad et al. 2011). Evidence exists that biochar will alter the physical nature of most soils to increase the water-holding capacity by increasing the soil surface area as well as pore space to improve drainage problems in clay soils (Lehmann and Joseph 2009). Adding biochar to soil can also result in reductions in acidity, improvement of the cation exchange capacity accelerating the composting process, and improved habitat for beneficial soil microbes, which can indirectly cause an increase in plant productivity (Blackwell et al. 2009). Bamboo char has been to shown to comprise of a broader range of pore sizes (0.001-1000 $\mu \mathrm{m}$ diameter) compared to wood-based biochar (10-3,000 $\mu \mathrm{m}$ diameter) (Thies and Rillig 2009), possibly enhancing the range of benefits provided by biochar originating from differing feedstocks.

Sugar has a dual function in plants, as both a nutrient and a signaling molecule (Roitsch 1999; Rolland et al. 2002). Energy expenditure in plants is necessary for establishment (root formation) and survival (respiration), consequently supplying the end product of photosynthesis (i.e., sucrose) as a soil amendment may allow plants to invest more energy in reversing losses encountered through transplanting (Percival 2007). Slow-release sugar compounds, such as molasses, have been proven to have significant effects on plant growth during germination, influencing the mobility of nutrients, shoot and hypocotyl development including suppressing elongation, cotyledon greening, and expansion (Rolland et al. 2002). Evidence from several experimental studies shows that sugar supplementation to young and mature trees can enhance root invigoration by increasing lateral root growth and root metabolism (Percival et al. 2004). Sugar as an organic amendment also has the potential to alter the soil rhizosphere populations, resulting in changes in plant nutrient uptake in favor of increased root growth (Blunden and Woods 1969).

BOOST Organic Granular is a premium-grade compound organic fertilizer with an N:P:K ratio of 9:6:3. Slow- and quick-release nitrogen is present to provide both instant greening and longer nutrient availability to the root system after application to the rhizosphere. Studies investigating the application of soil-incorporated synthetic fertilizers on establishment and growth of Magnolia grandiflora and silver maple (Acer saccharinum) transplants reported significant increases in stem diameter, height, and growth by the third growing season, (Schulte and Whitcomb 1975; Hensley et al. 1988). However, further studies using Pyrus calleryana 'Bradford' indicated no benefits from incorporating fertilizer at the time of planting, if the soil is already of sufficient fertility (Shoup et al. 1981). Consequently, data exists investigating the effect of synthetic fertilizers on tree growth; however, little work has been carried out studying the influence of organic fertilizers. Edmeades (2003) concludes that effects from long-term applications of organic and synthetic fertilizers are similar with both inducing large effects on soil productivity. Therefore, organic based fertilizers may have similar long term beneficial effects for transplanted trees. This trial's approach of the use of an organic fertilizer to stimulate root growth aims to generate new information. Likewise, although the influence of each of these soil amendments (biochar, molasses, organic fertilizers) has received some attention when applied individually the influence of combining these products has never been evaluated.

The objective of this study was therefore to evaluate the potential of these three soil amendments (biochar a purified form of carbon, a slow release molasses fertilizer and a organic $\mathrm{N}: \mathrm{P}: \mathrm{K}$ fertilizer) singly and in combination.

\section{MATERIALS AND METHODS}

Bare-rooted Pyrus communis 'Williams' Bon Chrétien' trees obtained from a commercial nursery grower (Blackmoor Nurseries, Blackmoor, Nr Liss, Hampshire, UK) were used for experimental pur- 
poses. Prior to planting, researchers pruned each tree to create a uniform root:shoot ratio of $0: 33-\mathrm{a}$ ratio associated with transplant stress (Aldhous and Mason 1994). Twenty-liter planting pits were excavated at the trial site located at University of Reading Shinfield Experimental Field Site, Cutbush Lane, Reading, Berkshire, UK (N51 $\left.43, \mathrm{~W}-1^{\circ} 08\right)$. The pruned stock was then planted directly into each pit and existing soil was combined with one or combinations of the following amendments:

Molasses pellets-crude protein (10\%), oil (1\%), digestible fiber (32\%), starch (1\%), sugar (20\%); Trident Feeds 64 Innovation Way, Lynch Wood, Peterborough, Cambridgeshire, UK.

Takesumi Ltd. biochar-100\% crushed pyrolysed bamboo biochar; Barrettine Group, St. Ivel Way, Warmley, Bristol, BS30 8TY UK.

BOOST Organic-organic nitrogen (9\%), phosphorus pentoxide $\left[\mathrm{P}_{2} \mathrm{O}_{5}(6 \%)\right]$, potassium oxide $\left[\mathrm{K}_{2} \mathrm{O}(3 \%)\right]$, pH 6.5, organic matter (62\%); Barrettine Group, St. Ivel Way, Warmley, Bristol, BS30 8TY UK.

Treatments were applied as follows: i) molasses pellets, ii) biochar, iii) BOOST Organic individually applied at $5 \%$ by soil volume (e.g., 1:19 ratio), iv) molasses $(2.5 \%$ by volume $)+$ biochar $(2.5 \%$ by volume), v) BOOST Organic ( $2.5 \%$ by volume) + biochar (2.5\% by volume), vi) molasses $(2.5 \%$ by volume $)+$ BOOST Organic $(2.5 \%$ by volume), vii) BOOST Organic (1.7\% by volume) + biochar ( $1.7 \%$ by volume $)+$ molasses $(1.7 \%$ by volume), viii) non-amended soil (controls).

A randomized complete block was used in the experimental design. Ten single-tree replications were used per treatment, giving a total of 80 observations per response variable. Treatments were applied only once at the time of planting and not repeated throughout the experimental period. Five percent by soil volume was selected as a planting treatment based on the results of Zwart and Kim (2012) and Percival et al. (2004). The soil at the time of planting was a sandy loam containing $4 \%-6 \%$ organic matter with a $\mathrm{pH}$ of 6.4 and available $\mathrm{P}, \mathrm{K}, \mathrm{Mg}, \mathrm{Na}$, and $\mathrm{Ca}$ were 50.0, 667.5, 182.3, 46.1 and $2,099 \mathrm{mg} \mathrm{L}$, respectively. Weeds were controlled chemically using glyphosate prior to planting (Roundup; Green-Tech, Sweethills Park, Nun Monkton, York, UK) and by hand during the trial. No irrigation was required. Height from the base of the trunk to the top of canopy was recorded at the time of experimental setup. Trees were planted on 22 February 2010 with ten trees per treatment. Treatment effects on growth, fruit yield, and vitality were monitored over two years, with measurements taken on 05 October 2011 and 30 September 2012 (i.e., toward the end of the two growing seasons). It is the general consensus of many researchers that results indicate that the first two years after transplanting are the most critical for survival (Gilbertson and Bradshaw 1990; Hitchmough 1994; Johnston and Rushton 1999).

\section{Tree Growth and Fruit Yield}

Survival was based on leaf flush and branch extension growth during the growing season. If no leaf flush and growth (branch extension) occurred, the tree was classified as dead. In support of this mortality classification, gently removing the peripheral epidermal layer on each side of the terminal branch with a scalpel revealed brown (rather than green viable) peridermal tissue (Jiang et al. 1999). Five live shoots were randomly selected throughout the crown to record stem extension measurements using a Precision Value Line Digitronic Caliper 110 Series (0-200mm; Moore and Wright Europe, Bowers Metrology, Bradford, West Yorkshire, UK), precise to the nearest 10 micrometers. Mean fruit yield was quantified by weighing all fruit on each tree at harvest and dividing by the number of trees per treatment. Crown volume $(\mathrm{Cv})$ was estimated from the crown width (D) and crown depth (L) using the paraboloid form of the crown (Kupka 2007).

$$
\mathrm{Cv}=\Pi \underline{\mathrm{D}^{2} \mathrm{~L}}
$$

8

\section{Tree Vitality}

Five leaves selected randomly throughout the crown per tree were analyzed for chlorophyll fluorescence and chlorophyll content measurements. Leaves were then tagged to ensure that only the same leaf was measured throughout.

\section{Chlorophyll Fluorescence}

Leaves were adapted to darkness for 30 minutes by attaching light-exclusion clips to the leaf surface, and chlorophyll fluorescence was then mea- 
sured using a Handy PEA portable fluorescence spectrometer (Hansatech Instruments Ltd., King's Lynn, UK). Measurements were recorded up to $1 \mathrm{sec}$ with a data-acquisition rate of $10 \mu \mathrm{s}$ for the first $2 \mathrm{~ms}$ and of $1 \mathrm{~ms}$ thereafter. The fluorescence responses were induced by a red (peak at $650 \mathrm{~nm}$ ) light of $1500 \mu \mathrm{mol} \mathrm{m}{ }^{-2}$. The Performance Index (PI), one of the parameters measured by the spectrometer, is an indicator of plant vitality. PI is an overall expression indicating the forces of redox reactions and can be used to describe the driving force of the photosynthesis occurring in leaf tissue (Strasser et al. 2004). PI has been shown to be a highly sensitive index to any form of abiotic stress and is recommended for the testing of potentially stressed plant stock (Strasser et al. 2000).

\section{SPAD}

Leaf chlorophyll content was estimated at the midpoint of the leaf next to the main leaf vein by using a handheld optical Minolta chlorophyll meter SPAD-502 (Spectrum Technologies, Inc. Plainfield, Illinois, U.S.). Calibration was obtained by measurement of absorbance at 663 and $645 \mathrm{~nm}$ in a spectrophotometer (PU8800 Pye Unicam, Portsmouth, UK) after extraction with $80 \% \mathrm{v} / \mathrm{v}$ aqueous acetone (regr. eq. $\mathrm{y}=5.66+$ $0.055 \mathrm{x} ; \mathrm{r}^{2}$ adj $=0.89, P \leq 0.01$; Lichtenthaler 1987).

\section{Photosynthetic Rates (Pn)}

Light-induced $\mathrm{CO}_{2}$ fixation (Pn) was measured using fully expanded leaves from near the top of the canopy (generally about four nodes down from the apex) by using an Infra-Red Gas Analyzer (LCA-2 ADC, BioScientific Ltd., Hoddesdon, Herts, UK). The irradiance subjected to the leaves was 700 to $800 \mathrm{~mol} \mathrm{~m}^{-2}$ photosynthetically active radiation saturating with respect to $\mathrm{Pn}$; the velocity of the airflow was $1 \mathrm{ml} \mathrm{s}^{-1}$ $\mathrm{cm}^{-2}$ of leaf area. Calculation of the photosynthetic rates was carried out according to Von Caemmerer and Farquhar (1981). Two leaves per tree were selected for measurements.

\section{Statistical Analysis}

Treatment effects on chlorophyll fluorescence, photosynthetic rates, chlorophyll concentrations, fruit yield, and growth were determined by both two- and one-way Analyses of Variance (ANOVA) as checks for normality and equal variance distributions were met using an Anderson-Darling test. Differences between treatment means from non-treated controls were separated by Tukey's Honestly Significant Difference (HSD) test at the 95\% confidence level $(P>0.05)$ using the 'GenStat for Windows 16th edition' statistics system (VSN International Ltd., Hemel Hempstead, UK).

\section{RESULTS}

\section{Tree Growth}

All soil amendments reduced mortality of Pyrus communis 'Williams' Bon Chrétien' after planting compared to non-treated controls, demonstrating all soil amendments evaluated in this study have the potential to promote transplant survival (Table 1). Likewise in both the first and second growing seasons, soil amendment with biochar, molasses pellets, and organic fertilizer individually increased tree growth in terms of fruit yield and crown volume. These increases were, in most cases, significant $(P<0.05)$ following soil amendment with biochar and BOOST Organic but non-significant following amendment with molasses pellets. Increases in fruit yield per tree ranged from 19.3\% (slow-release molasses pellets) to $46.7 \%$ (BOOST Organic), while increases in crown canopy ranged from $14.4 \%$ (slow-release molasses pellets) to $31.1 \%$ (BOOST Organic) over non-amended soils when averaged over two growing seasons. Combination of amendments always resulted in an increased fruit yield per tree and crown canopy coverage compared to use of an amendment individually.

For example, in Year 1 amendment with biochar or BOOST Organic increased fruit yield per tree from $5.8 \mathrm{~kg}$ (non-amended controls) to 6.6 and $6.8 \mathrm{~kg}$, respectively. Soil amended with a combination of biochar + BOOST Organic increased fruit yield per tree to $7.2 \mathrm{~kg}$. When averaged over two growing seasons, combining products enhanced fruit yield per tree and canopy coverage by $12 \%-$ $49 \%$. Such a response indicates that combination of amendments tested in this study induce additive effects compared to application individually. Based on fruit yield per tree, positive effects were in the following order: BOOST Organic + biochar > BOOST Organic > BOOST Organic + 
molasses $>$ BOOST Organic + biochar + molasses $>$ molasses + biochar $>$ biochar $>$ molasses $>$ controls, when averaged over two growing seasons.

A similar ranking order was recorded for crown canopy coverage: BOOST Organic + biochar $>$ biochar $>$ molasses + biochar $>$ BOOST Organic $>$ BOOST Organic + biochar + molasses $>$ BOOST Organic + molasses $>$ molasses $>$ controls, when data was averaged over two growing seasons.

\section{Tree Vitality}

In both the first and second growing season, soil amendment with biochar, molasses pellets, and an organic N:P:K fertilizer individually increased tree vitality [chlorophyll fluorescence (PI), leaf chlorophyll content (SPAD), and photosynthetic rates]. In the majority of cases, these increases were significant $(P<0.05)$. For example, increases in chlorophyll content (SPAD) ranged from $4.5 \%$ (slow-release molasses pellets) to $27.5 \%$ (BOOST Organic), increases in PI values ranged from $13.7 \%$ (slow-release molasses pellets) to $59.9 \%$ (BOOST Organic), while increases in Pn ranged from 9.6\% (slow-release molasses pellets) to $25.3 \%$ (BOOST Organic) over non-amended soils, when averaged over two growing seasons.

Combination of amendments resulted in an increase in tree vitality [chlorophyll fluorescence, leaf chlorophyll content (SPAD), photosynthetic rates] compared to use of an amendment individually. For example, in Year 1, amendment with biochar or BOOST Organic increased leaf chlorophyll content from 38.7 (non-amended controls) to 44.5 and 49.9 , respectively. Soil amended with a combination of biochar + BOOST Organic increased leaf chlorophyll content to 50.8. Averaged over two growing seasons, combining products enhanced chlorophyll fluorescence (PI), leaf chlorophyll content (SPAD), and photosynthetic rates by $12 \%-77 \%$. Such a response indicates that combination of amendments tested in this study induce additive effects of tree vitality compared to individual application. Based on leaf chlorophyll content, positive effects were in the following order: BOOST Organic + biochar $>$ BOOST Organic $>$ BOOST Organic + biochar + molasses $>$ BOOST Organic + molasses $>$ molasses + biochar $>$ biochar $>$ molasses $>$ controls, when averaged over two growing seasons. A similar ranking order was recorded for PI and Pn values: BOOST Organic + biochar $>$ BOOST Organic + biochar + molasses $>$ BOOST Organic $>$ BOOST Organic + molasses $>$ molasses + biochar $>$ biochar $>$ molasses $>$ controls, when averaged over two growing seasons.

\section{DISCUSSION}

All soil amendments evaluated in this study improved transplant survival in the critical first growing season after planting. Although supporting evidence exists that amendments, such as carbohydrates, organic nitrogen formulations, and biochar, can positively influence transplant survival, this study generates new and novel data by assessing different formulations of each amendment to include a pelletized slow-release form of carbohydrate (molasses) rather than liquid, biochar derived from a purely bamboo feedstock origin, and a new organic N:P:K fertilizer

Table 1. The influence of soil amendments on growth, tree vitality, and mortality of Pyrus communis 'Williams' Bon Chrétien' in Year 1.

\begin{tabular}{|c|c|c|c|c|c|c|}
\hline \multirow[t]{2}{*}{ Treatment } & \multicolumn{3}{|c|}{ Tree vitality } & \multicolumn{3}{|l|}{ Growth } \\
\hline & SPAD & PI & Pn & $\begin{array}{l}\text { Fruit yield/ } \\
\text { tree }(\mathrm{kg})\end{array}$ & $\begin{array}{l}\text { Crown } \\
\text { volume }\end{array}$ & $\begin{array}{l}\text { Mortality } \\
\text { (\%) }\end{array}$ \\
\hline Control (no amendment) & 38.7 & 6.2 & 4.01 & 5.8 & 0.60 & 20 \\
\hline Molasses pellets & $42.3^{\text {ns }}$ & $7.1^{*}$ & $4.45^{\mathrm{ns}}$ & $6.1^{\mathrm{ns}}$ & $0.68^{\mathrm{ns}}$ & 0 \\
\hline Biochar & $44.5^{\mathrm{ns}}$ & $8.2^{*}$ & $4.48^{\mathrm{ns}}$ & $6.6^{\mathrm{ns}}$ & $0.77^{*}$ & 0 \\
\hline BOOST Organic granular & $49.9^{*}$ & $8.2^{*}$ & $4.56^{\mathrm{ns}}$ & $6.8^{\star}$ & $0.77^{\star}$ & 0 \\
\hline $\begin{array}{l}\text { BOOST Organic granular + } \\
\text { biochar }\end{array}$ & $50.8^{*}$ & $10.0^{*}$ & $4.66^{\mathrm{ns}}$ & $7.2^{*}$ & $0.88^{*}$ & 0 \\
\hline $\begin{array}{l}\text { BOOST Organic granular + } \\
\text { molasses pellets }\end{array}$ & $47.9^{*}$ & $7.4^{*}$ & $4.38^{\text {ns }}$ & $6.7^{*}$ & $0.72^{*}$ & 0 \\
\hline Molasses pellets + biochar & $47.1^{*}$ & $9.4^{*}$ & $4.61^{\mathrm{ns}}$ & $7.0^{*}$ & $0.81^{*}$ & 0 \\
\hline $\begin{array}{l}\text { BOOST Organic granular }+ \\
\text { molasses pellets + biochar }\end{array}$ & $50.3^{*}$ & $11.1^{*}$ & $4.50^{\text {ns }}$ & $6.8^{*}$ & $0.76^{*}$ & 0 \\
\hline
\end{tabular}

Notes: All values mean of surviving trees from an initial number of 10 . Asterisk $\left(^{*}\right)=$ significant differences between means $(P=0.05) . P<0.05$ are considered significant based on Tukey's Honestly Significant Difference test. SPAD = estimated leaf chlorophyll content, PI = chlorophyll fluorescence, Pn $=$ light-induced CO fixation. 
formulation. Previous research has shown that all three amendments in different forms influence host plant physiology and soil conditions to promote tree vitality, growth, and improve transplant survival rates. Application of carbohydrates, such as sucrose, as a root drench or in combination with a water-holding gel, improved transplant survival through enhanced root growth of silver birch (Betula pendula Roth.) and European beech (Fagus sylvatica L.) (Percival et al. 2004; Percival and Barnes 2007). Alterations in microbial populations initiated by the application of sucrose within the rhizosphere could favor root growth. In addition, carbohydrates may have functioned as direct nutrients for tree growth and influenced sugar-sensing processes that initiated changes in gene expression associated with root development (Koch 1996; Rolland et al. 2002).

Nutrient reserves accumulated the previous year are of primary importance for early spring growth. The quantity of stored nutrient reserves can be increased by a supply of nitrogen fertilizer during the growing season, due to the fact that nitrogen promotes higher leaf chlorophyll, and by default increases photosynthetic productivity later into the growing season (Tromp 1983; Cheng and Robinson 2004). Chlorophyll content in leaves is proportional to nitrogen, since leaf nitrogen is stored in the chloroplasts. Therefore, increases in nitrogen supply through fertilization are known to increase leaf chlorophyll content (Chandler and Dale 1994; Bondada and Syvertsen 2003), which would account for the improved leaf chlorophyll content and fluorescence values recorded in this experiment following application of an organic $\mathrm{N}: \mathrm{P}: \mathrm{K}$ fertilizer singly and in combination.

This research also differs from other studies in that it is the first to evaluate combinations of slowrelease carbohydrates, organic nitrogen fertilizers, and biochar as soil amendments on transplant survival. Results consistently demonstrate positive effects on tree vitality (chlorophyll fluorescence, leaf chlorophyll content, and photosynthetic rates) and growth (fruit yield per tree and canopy coverage) when these products are combined and incorporated as a soil amendment at the time of planting (Table 2). Applications of BOOST Organic plus biochar had the highest significance in promoting tree vitality and growth in most cases throughout two growing seasons. Organic fertilizer additions have also been shown to increase the organic matter content and nutrient concentrations in the soil, especially nitrogen pools, although this can result in excessive nitrogen accumulation and therefore leaching (Edmeades 2003). Biochar improves nutrient retention capacity, allowing the additions of fertilizer to be adsorbed by the porous biochar and reducing leaching of surplus nutrients (Blackwell et al. 2009; Lehmann and Joseph 2009). Consequently, combining an organic nitrogen-based fertilizer (BOOST Organic) with biochar may permit greater fertilizer retention in the rhizosphere, in turn increasing nutrient accessibility in the root zone (Lehmann and Joseph 2009). In support of this, Dempster et al. (2012) recorded reductions in levels of cumulative $\mathrm{NO}_{3}^{-}$(nitrate) leached of $25 \%$ over 21 days, and decreased cumulative $\mathrm{NH}_{4}^{+}$ (ammonium) leaching by approximately $20 \%$ when using eucalyptus-derived biochar in sandy soil. In addition, beneficial soil microbes, such as phosphate-solubilizing bacteria, mycorrhization-helper bacteria, and higher rates of mycorrhizal colonization are encouraged by the addition of biochar into the soil (Warnock et al. 2007). PI values as a measure of photosynthetic efficiency were significantly improved with BOOST Organic plus biochar soil amendment in the first year after transplanting. Transplant stress often deteriorates leaf cell components-including chloroplasts-damaging both photosystems I and II that manifest visibly in yellowing leaves (Percival 2007). Higher PI values compared to non-soil-amended controls indicate a superior operational level of photosynthetic efficiency, and are, by default, indicative of lower stress levels within the plant (Percival 2007). Consequently, a combination of these benefits may have accounted for the positive effects on tree vitality and growth recorded in this study, induced by the organic fertilizer/biochar combination. However, care needs to be taken following the addition of biochar as a soil amendment, as nutrient drawdown can occur at excessively high biochar additions. Nutrient drawdown relates to the availability of nutrients and their use over time within soil. A biochar soil amendment may induce soil nitrogen immobilization, possibly through an increase in soil microbial activity (Clough et al. 2013). 
Table 2. The influence of soil amendments on growth, tree vitality, and mortality of Pyrus communis 'Williams' Bon Chrétien' in Year 2.

\begin{tabular}{|c|c|c|c|c|c|c|}
\hline \multirow[t]{2}{*}{ Treatment } & \multicolumn{3}{|c|}{ Tree vitality } & \multicolumn{3}{|l|}{ Growth } \\
\hline & SPAD & PI & Pn & $\begin{array}{l}\text { Fruit yield/ } \\
\text { tree }(\mathrm{kg})\end{array}$ & $\begin{array}{l}\text { Crown } \\
\text { volume }\end{array}$ & $\begin{array}{l}\text { Mortality } \\
(\%)\end{array}$ \\
\hline Control (no amendment) & 41.5 & 4.0 & 3.90 & 4.5 & 0.71 & 0 \\
\hline Molasses pellets & $41.3^{\mathrm{ns}}$ & $4.6^{\mathrm{ns}}$ & $4.22^{\mathrm{ns}}$ & $6.0^{*}$ & $0.82^{\text {ns }}$ & 0 \\
\hline Biochar & $45.5^{\mathrm{ns}}$ & $6.2^{*}$ & $4.50^{*}$ & $6.2^{*}$ & $0.95^{*}$ & 0 \\
\hline BOOST Organic granular & $52.3^{*}$ & $7.5^{*}$ & $4.62^{*}$ & $7.8^{\star}$ & $0.84^{*}$ & 0 \\
\hline $\begin{array}{l}\text { BOOST Organic granular + } \\
\text { biochar }\end{array}$ & $55.8^{*}$ & $7.7^{\star}$ & $4.48^{*}$ & $7.8^{*}$ & $0.90^{*}$ & 0 \\
\hline $\begin{array}{l}\text { BOOST Organic granular + } \\
\text { molasses pellets }\end{array}$ & $50.9^{*}$ & $7.0^{*}$ & $4.46^{*}$ & $7.2^{*}$ & $0.82^{*}$ & 0 \\
\hline Molasses pellets + biochar & $48.8^{*}$ & $6.1^{*}$ & $4.60^{*}$ & $5.9^{*}$ & $0.87^{\star}$ & 0 \\
\hline $\begin{array}{l}\text { BOOST Organic granular }+ \\
\text { molasses pellets }+ \text { biochar }\end{array}$ & $51.1^{*}$ & $6.9^{*}$ & $4.39^{*}$ & $6.6^{*}$ & $0.83^{*}$ & 0 \\
\hline
\end{tabular}

Combinations of organic fertilizer and molasses also induced positive effects on tree vitality and growth, although not to the same extent as organic fertilizer plus biochar. Work by Percival and Barnes (2007), studying European beech, recorded higher mortality rates in control trees (40\%) compared to a water-retaining gel, synthetic nitrogen fertilizer, and carbohydrate (sucrose) combination following transplanting, where losses were reduced to $10 \%$. Promotion of lateral root growth can increase water availability by directly extending the rhizosphere, allowing increased water uptake, which reduces internal water deficit; a major contributing factor to transplant death (Gilbertson and Bradshaw 1990; Grossnickle 2005). Exposing root systems to high levels of carbohydrates has been shown to favor root development at the expense of net photosynthesis due to the repression of photosynthetic genes (Koch 1996). Sugar application to the rhizosphere has been acknowledged to repress shoot and leaf development in favor of root elongation due to the initiation of these storage processes. Therefore, application of slow-release sugar molasses may have influenced crucial metabolic processes, leading to the repression of genes involved with leaf growth and photosynthesis. Results for crown volume possibly reflect this priority toward root growth, as canopy coverage was not significantly increased when molasses was applied individually or in combination with BOOST Organic or biochar. In several studies, sugar has likewise been identified to repress nutrient mobilization, including nitrogen (Rolland et al. 2002; Hong et al. 2012), which is a possible explanation for the lack of effect on leaf chlorophyll content (SPAD values) over the two growing seasons. However, by Year 2, the sugar molasses may have been depleted within the soil and root system and exhausted of any root enhancing substances, hence the greater canopy coverage and higher chlorophyll content recorded in Year 2, where the benefits of the longer soil-persisting organic fertilizer and biochar become apparent.

Combining amendments enhanced tree vitality and growth $6 \%-18 \%$ compared to addition of each amendment alone. This may influence the economic viability of combining products (i.e., is such a percent increase worth the extra expense of combining products). Given that biochar degradation in the soil is low-i.e., a one-off application can last 500 to 20,000 years, as demonstrated by longevity studies of this substance in the Brazilian Amazon region of Terra Preta de Indio-the many benefits of biochar additions to the soil will have long-term positive implications on future tree growth and vitality (Blackwell et al. 2009). The value of soil amended by biochar ensures a one-off biochar soil amendment would prove an economically viable option (e.g., providing improved soil structure and pore space, enhanced nutrient supply to plants, higher soil nutrient retention, enhanced efficiency of fertilizer use, reduced nutrient leaching in turn resulting in superior plant performance, and elevated tissue nutrient concentrations from 500 to 20,000 years).

In conclusion, results from this investigation indicate additions of the assessed soil amendments have several benefits. All amendments decreased 
mortality in the first year after transplanting from $20 \%$ to $0 \%$, indicating that they successfully improved transplant survival the first year after replanting, at least with Pyrus communis 'Williams' Bon Chrétien'. With such a large cost generated from replacing declining trees from transplant stress, the results have useful implications for the commercial, production, and amenity landscaping industries.

\section{LITERATURE CITED}

Aldhous, J.R., and W.L. Mason. 1994. Forest nursery practice. Forestry Commission Bulletin No 111. HMSO, London, UK.

Blackwell, P., G. Riethmuller, and M. Collins. 2009. Biochar applications in soil. pp. 207-226. In: J. Lehmann and S. Joseph (Eds.). Biochar for Environmental Management: Science and Technology. Earthscan, London, UK.

Blunden, G., and D.L. Woods. 1969. Effect of carbohydrates in seaweed fertilizers. Proceedings of the 6th International Seaweed Symposium. pp. 647-653.

Bondada, B.R., and J.P. Syvertsen. 2003. Leaf chlorophyll, net gas exchange, and chloroplast ultrastructure in citrus leaves of different nitrogen status. Tree Physiology 23:553-559.

Chandler, J.W., and E. Dale. 1994. Nitrogen deficiency and fertilization effects on needle growth and photosynthesis in Sitka spruce (Picea sitchensis). Tree Physiology 15:813-817.

Cheng, L., and T.L. Robinson. 2004. Management of nitrogen and carbohydrate reserves to improve growth and yield of apple trees. New York Fruit Quarterly 12:19-22.

Clough, T.J., L.M. Condron, C. Kammann, C. Muller. 2013. A review of biochar and soil nitrogen dynamics. Agronomy 3:275-293.

Dempster, D.N., D.L. Jones, and D.M. Murphy. 2012. Clay and biochar amendments decreased inorganic but not dissolved organic nitrogen leaching in soil. Soil Research 50:216-221.

Edmeades, D.C. 2003. The long term effects of manures and fertilizers on soil productivity and quality: A review. Nutrient Cycling in Agroecosystems 66:165-180.

Elad, Y., E. Cytyrn, Y.M. Harel, B. Lew, and E.R. Graber. 2011. The biochar effect: Plant resistance to biotic stresses. Phytopathologia Mediterranea 50:335-349.

Gilbertson, P., and A.D. Bradshaw. 1990. The survival of newly planted trees in inner cities. Arboricultural Journal 14:287-309.

Grossnickle, S.C. 2005. Importance of root growth in overcoming plant stress. New Forests 30:273-294.

Hensley, D.L., R.E. McNiel, and R. Sundheim. 1988. Management influences on growth of transplanted Magnolia grandiflora. Journal of Arboriculture 14:204-207.

Hirons, A.D., and G.C. Percival. 2012. Fundamentals of tree establishment: A review. pp. 51-62. In: M. Johnston and G.C. Percival (Eds.). Trees, People, and the Built Environment. Forestry Commission, Edinburgh, UK.

Hitchmough, J.D. 1994. Urban Landscape Management. Inkata Press Pty Ltd, Chatswood, Australia.

Hong, Y.F., T-H.D. Ho, C.F. Wu, S.L. Ho, R-H. Yeh, C.A. Lu, P.W. Chen, L.C. Yu, A. Chao, and S.M. Yu. 2012. Convergent starvation signals and hormone crosstalk in regulating nutrient mobilization upon germination in cereals. The Plant Cell 24:2857-2873
Johnston, M., and B.S. Rushton. 1999. A Survey of Urban Forestry in Britain. University of Ulster, Coleraine, Northern Ireland, UK.

Jiang, H., G.S. Howell, and J.A. Flore. 1999. Efficacy of chlorophyll fluorescence as a viability test for freeze-stressed woody grape tissue. Canadian Journal of Plant Science 79:401-409.

Koch, K.E. 1996. Carbohydrate-modulated gene expression in plants. Annual Review of Plant Biology 47:509-540.

Kozlowski, T.T., and W.J. Davies. 1975. Control of water balance in transplanting trees. Journal of Arboriculture 1:1-10.

Kupka, I. 2007. Growth reaction of young wild cherry (Prunus avium L.) trees to pruning. Journal Forest Science 53:555-560.

Lehmann, J., and S. Joseph. 2009. Biochar for Environmental Management: Science and Technology. Earthscan, London, UK.

Lichtenthaler, H.K. 1987. Chlorophylls and carotenoids: Pigments of photosynthetic biomembranes. Methods in Enzymology 148:350-382.

McKay, H.M., R.L. Jinks, and C. McEvoy. 1999. The effect of desiccation and rough-handling on the survival and early growth of ash, beech, birch, and oak seedlings. Annals of Forest Science 56:391-402.

Nowak, D.J., D.E. Crane, and J.C. Stevens. 2006. Air pollution removal by urban trees and shrubs in the United States. Urban Forestry \& Urban Greening 4:115-123.

Percival, G.C. 2007. Post-planting: Getting to the root of the problem. June edition EssentialARB 22:18-24.

Percival, G.C., and S. Barnes. 2007. The influence of carbohydrates, nitrogen fertilizers and water-retaining polymer root dips on survival and growth of newly transplanted bare-rooted silver birch (Betula pendula Roth.) and European beech (Fagus sylvatica L.). Arboricultural Journal 30:223-244.

Percival, G.C., G.A. Fraser, and S. Barnes. 2004. Soil injections of carbohydrates improve fine root growth of established urban trees. Arboricultural Journal 28:95-101.

Roitsch, T. 1999. Source-sink regulation by sugar and stress. Current Opinion in Plant Biology 2:198-206.

Rolland F., B. Moore, and J. Sheen. 2002. Sugar sensing and signaling in plants. The Plant Cell 14:185-205.

Schulte, J.R., and C.E. Whitcomb. 1975. Effects of soil amendments and fertilizer levels on the establishment of silver maple. Journal of Arboriculture 1:192-195.

Shoup, S., R. Reavis, and C.E. Whitcomb. 1981. Effects of pruning and fertilizers on establishment of bare-root deciduous trees. Journal of Arboriculture 7:155-157.

Smardon, R.C. 1988. Perception and aesthetics of the urban environment: Review of the role of vegetation. Landscape and Urban Planning 15:85-106.

Strasser, R.J., A. Srivastava, and M. Tsimilli-Michael. 2000. The fluorescence transient as a tool characterize and screen photosynthetic samples. In: M. Yunus, U. Pathre, and P. Mohanty (Eds.). Probing Photosynthesis. Mechanisms, Regualtion and Adaptation. Taylor and Francis, London, UK.

Strasser R.J., M. Tsimilli-Michael, and A. Srivastava. 2004. Analysis of the chlorophyll a fluorescence transient. pp. 321-362. In: G.C. Papageorgiou and Govindjee (Eds.). Chlorophyll a fluorescence: A signature of photosynthesis. Springer, Dordrecht, The Netherlands.

Susca, T., S.R. Gaffin, and G.R. Dell'Osso. 2011. Positive effects of vegetation: Urban heat island and green roofs. Environmental Pollution 159:2119-2126. 
Thies, J.E., and M.C. Rillig. 2009. Characteristics of biochar: biological properties. pp. 85-106. In: J. Lehmann and S. Joseph (Eds.). Biochar for Environmental Management: Science and Technology. Earthscan, London, UK.

Tromp, J. 1983. Nutrient reserves in roots of fruit trees, in particular carbohydrates and nitrogen. Plant and Soil 71:401-413.

Von Caemmerer, S., and G.D. Farquhar. 1981. Some relationships between the biochemistry of photosynthesis and the gas exchange of leaves. Planta 153:376-387.

Warnock, D.D., J. Lehmann, T.W. Kuyper, and M.C. Rillig. 2007. Mycorrhizal responses to biochar in soils-Concepts and mechanisms. Plant Soil 300:2-90.

Watson, G.W., and E.B. Himelick. 1982. Seasonal variation in root regeneration of transplanted trees. Journal of Arboriculture 8:305-310.

Zwart, D.C., and S.H. Kim. 2012. Biochar amendment increases resistance to stem lesions caused by Phytophthora spp. in tree seedlings. HortScience 47:1736-1740.

\section{Emma Schaffert \\ Research Technician \\ Bartlett Tree Experts Research Laboratory \\ Cutbush Lane, Shinfield \\ Reading, Berkshire RG2 9AF, UK \\ lhailey@bartlettuk.com}

\section{Glynn C. Percival (corresponding author) \\ Bartlett Tree Experts Research Laboratory \\ Cutbush Lane, Shinfield \\ Reading, Berkshire RG2 9AF, UK \\ gpercival@bartlettuk.com}

Résumé. Des taux élevés de mortalité surviennent lors de la transplantation de végétaux à racines nues dans des aménagements urbains où des conditions de sol inadéquates, nommément une faible fertilité et une mauvaise structure édaphique, sont souvent rencontrées. Associées à un suivi post-plantation insuffisant, ces pertes représentent d'importantes pertes économiques pour l'industrie. Des études antérieures ont démontré que le stress de la transplantation est réduit et que le taux de survie est plus élevé avec l'ajout d'amendements lors de la plantation afin d'améliorer les conditions de sol. L'efficacité de trois amendements de sol appliqués seuls ou en combinaison, soit le charbon à usage agricole, la mélasse à libération lente et un engrais organique N-P-K, ont été testés en vue d'établir leur potentiel à réduire les pertes suite à la transplantation de poiriers 'Williams' (Pyrus communis 'Williams' Bon Chrétien). Les résultats de cette recherche ont montré que l'utilisation de ces amendements de sol a eu, dans la quasi- totalité des cas, des effets positifs significatifs sur la croissance des arbres et leur vitalité au cours des deux saisons de croissance suivantes. Par exemple, tous les amendements ont réduit la mortalité du poirier 'Williams' ( $P y$ rus communis 'Williams' Bon Chrétien) de $20 \%$ comparativement au taux de mortalité des arbres témoins, tandis que la production de fruits a été augmentée ainsi que la couverture de la canopée selon des proportions moyennes de $19,3 \%$ à $46,7 \%$ et de $14,4 \%$ à 31,1 $\%$ comparativement à des sols non amendés après deux saisons de croissance. Les amendements avec le charbon à usage agricole combiné avec un engrais organique N-P-K, et l'engrais organique N-P-K utilisé seul, ont démontré en moyenne les plus fortes améliorations de vitalité et de croissance. Les résultats indiquent que l'utilisation d’amendements avec le charbon à usage agricole, la mélasse à libération lente et un engrais organique N-P-K offrent un potentiel pour l'amélioration de la survie des végétaux à racines nues transplantés et à une bonne reprise du poirier 'Williams' Bon Chrétien.

Zusammenfassung. Hohe Absterberaten resultieren aus der Verpflanzung von Wurzelware an urbane Standorte, wo oft ungeeignete Bodenbedingungen, wie geringe Fruchtbarkeit und ungeeignete Bodenstrukturen vorkommen. Gepaart mit unzureichender Nachsorge können diese Verluste zu hohen ökonomischen Verlusten in der Industrie führen. Vorangegangene Studien haben gezeigt, dass es durch die Zufügung von Bodenverbesserungsstoffen während der Pflanzung zu höheren Überlebensraten und weniger Stress für die Pflanzen führen kann. Die Effektivität von drei Bodenverbesserungsstoffen, die einzeln oder in Kombination zugefügt wurden - Bio-Holzkohle, langsam abbauende Molasse und ein organischer NPK-Dünger - wurden auf ihr Potential zur Reduzierung von Gehölzverlusten während der Pflanzung von Pyrus communis 'Williams' Bon Chrétien untersucht. Die Resultate dieser Untersuchung zeigten, dass die Verwendung dieser Bodenzuschlagstoffe in geradezu allen Fällen zu signifikant positiven Effekten auf das Baumwachstum und die Vitalität zwischen den beiden folgenden Wachstumsperioden geführt hat. Zum Beispiel reduzierten alle Zuschlagstoffe die Mortalität von Pyrus communis 'Williams' Bon Chrétien' um 20\% im Vergleich zu Keinem in der Kontrollgruppe, während die Zuwachsraten in Fruchtertrag und Kronendichte pro Baum zwischen $19.3 \%$ bis $46.7 \%$ und $14.4 \%$ bis 31.1\% mehr im Durchschnitt aus zwei Vegetationsperioden als in nicht verbesserten Böden betragen. Der Zuschlag von Biokohle mit einem organischen NPK-Dünger und einem NPK-Dünger allein zeigte im Durchschnitt den höchsten Verbesserungseinfluss in Bezug auf Wachstum und Vitalität. Die Resultate verdeutlichen, dass die Verwendung von Bio-Holzkohle, langsam abbauende Molasse und einem organischen NPK-Dünger ein Potential zur Verbesserung der Verpflanzung und Standortetablierung von Wurzelware von Pyrus communis 'Williams' Bon Chrétien bieten.

Resumen. Resultaron altas tasas de mortalidad al trasplantar plantas a raíz desnuda en paisajes urbanos, donde a menudo existen condiciones de suelos inadecuados, tales como la baja fertilidad y mala estructura. Junto con el poco cuidado posterior, esto puede causar grandes pérdidas económicas a la industria. Estudios anteriores han demostrado el bajo estrés del trasplante y mayores tasas de supervivencia con la adición de enmiendas del suelo al momento de la plantación para mejorar las condiciones del suelo. Se investigó la eficacia de tres enmiendas del suelo aplicados individualmente y en combinación - biochar, melaza de liberación lenta, y una fertilizante orgánico: N:P:K para saber su potencial para reducir las pérdidas de trasplante de Pyrus communis 'Williams' Bon Chrétien. Los resultados de esta investigación mostraron que el uso de estas enmiendas del suelo en casi todos los casos tuvo efectos positivos significativos sobre el crecimiento del árbol y la vitalidad a través de dos estaciones de crecimiento. Por ejemplo, todas las enmiendas reducen la mortalidad de Pyrus communis 'Williams' Bon Chrétien 'en un $20 \%$ en comparación con los controles tratados, mientras que los aumentos en el rendimiento de la fruta y la cobertura del dosel por árbol varió de $19,3 \%$ a $46,7 \%$ y $14,4 \%$ a $31,1 \%$ en suelos no tratados, en dos estaciones de crecimiento. Las enmiendas de biochar con un N:P:K orgánico y un N:P:K solo, mostraron, en promedio, las mayores mejoras en la vitalidad y el crecimiento. Los resultados indican que el uso de las enmiendas de biochar, la melaza de liberación lenta, y N:P:K orgánico ofrecen potencial para aumentar la supervivencia del trasplante a raíz desnuda y el establecimiento de Pyrus communis 'Williams' Bon Chrétien. 